\title{
Contextual Based Learning Media Development to Train Creative Thinking Skill in Primary School
}

\author{
Zaky Adhitya Ginanjar Sasmita ${ }^{1}$, Wahono Widodo ${ }^{2}$, Sifak Indana ${ }^{3}$ \\ 1,2,3 State University of Surabaya, Surabaya, Indonesia
}

\begin{tabular}{|c|c|}
\hline 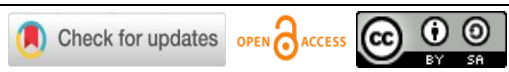 & DOI : https://doi.org/10.46245/ijorer.v2i4.124 \\
\hline Sections Info & ABSTRACT \\
\hline Article history: & The goal of this research is to produce learning media used context make pia \\
\hline Submitted: June 25, 2021 & cake that has category valid, practical and effective to train creativity thinking \\
\hline Final Revised: July 18, 2021 & learning in primary school students. The research was conducted in 5 th grade \\
\hline Accepted: July 29, 2021 & elementary school as many as 30 students. The research method used is three \\
\hline Online: July 31, 2021 & stages of the $4 \mathrm{D}$ model, namely definition, planning, development with the \\
\hline Keyword & design of one group pretest - posttest design. This research produces 1) \\
\hline conte & validity data syllabus (very valid), lesson plan (valid), teaching materials \\
\hline king skill & (valid), worksheet (very valid) and creative thinking skills test (valid); 2) \\
\hline learning media & Practicality data taken from the implementation practicality of lesson plan \\
\hline primary school & with good criteria; 3) The effectiveness of the device produces an N- Gain \\
\hline 回我证回 & $\begin{array}{l}\text { category, flexibility originality and elaboration are medium. The student's } \\
\text { response shows delight and intrigue when learning is done using the } \\
\text { development of contextual learning devices to train students' creative thinking } \\
\text { skills. }\end{array}$ \\
\hline
\end{tabular}

\section{INTRODUCTION}

High-level thinking is urgently needed to fulfil the needs of life in the 21st century. High-level thinking is creative thinking and critical thinking, creative thinking is building ideas applied in daily life (Susanto, 2016). High-level thinking generates opportunities for job creation in several skills, this can form a new civilization (Kemdikbud, 2016). Creative thinking ability is a way of thinking to find new insights, new approaches, new perspectives and understand new things (Eragamreddy, 2013) Training creative thinking skills is very necessary in addition to soft skills can also improve students' learning outcomes (Widiawati, 2019). Improving creative thinking skills is also needed to help students find problem solving (Suwandari, 2019).

From the global creativity index data in terms of technology, talent and tolerance Indonesia is still ranked 115th out of 139 countries. PISA (2018) showed the ranking of acquisition is not so different in 2015, Indonesia has not entered the top 10 PISA rankings (OECD, 2019). Referring to PISA data Indonesia is still weak in terms of numeration ability of literacy. Training creative thinking skills can be done by putting together interactive, inspiring, fun and challenging learning as a vehicle for initiative and creativity of students (Rusman, 2011). Learning tools are an important component to train students' creative thinking skills (Inayah, 2016).

One component of learning device has a training function is the student activity sheet (Herianto, 2020). Learning that links the material in the classroom with the real life around students can help students practice their creative thinking skills. Learning in the classroom with contextual learning has a fundamental difference Neka et al (2015). 
Creative thinking denifined cognitivite activites by comprehensive according specific object, problem and condition/type of effort toward in the problem based on capacity.

Contextual learning is also useful for improving student learning outcomes (Muhlisin, 2012). Learning by utilizing the context that exists around students is able to encourage students' interest in learning (Purwanti, 2012). Contextual-based learning can help students practice creative thinking skills rather than using conventional classes (Winarti, 2015). Contextual learning can also improve students' literacy skills which are needed as a provision to train creative thinking skills, namely generating new ideas, ideas and even opinions (Rohmawati, 2018). Contextual-based learning around students can increase students' motivation and learning outcomes (Amunutu, 2016, Safaruddin et al., 2020). Creative thinking skills can be trained continuously in the world of formal education, namely schools (Hwang et al., 2015). Students can easily practice creative thinking if it is connected to the surrounding context or learning media that can be observed directly. For contextual-based learning environment students improve creative thinking skills.

\section{RESEARCH METHOD}

The purpose of this study is to create a valid, practical and effective learning tool to improve students' creative thinking skills based on the contextual surrounding of students, namely pie cake making. This processed in three stage define, design and development (Thiagarajan, 1974). Flowchart in research shows in Figure 1.

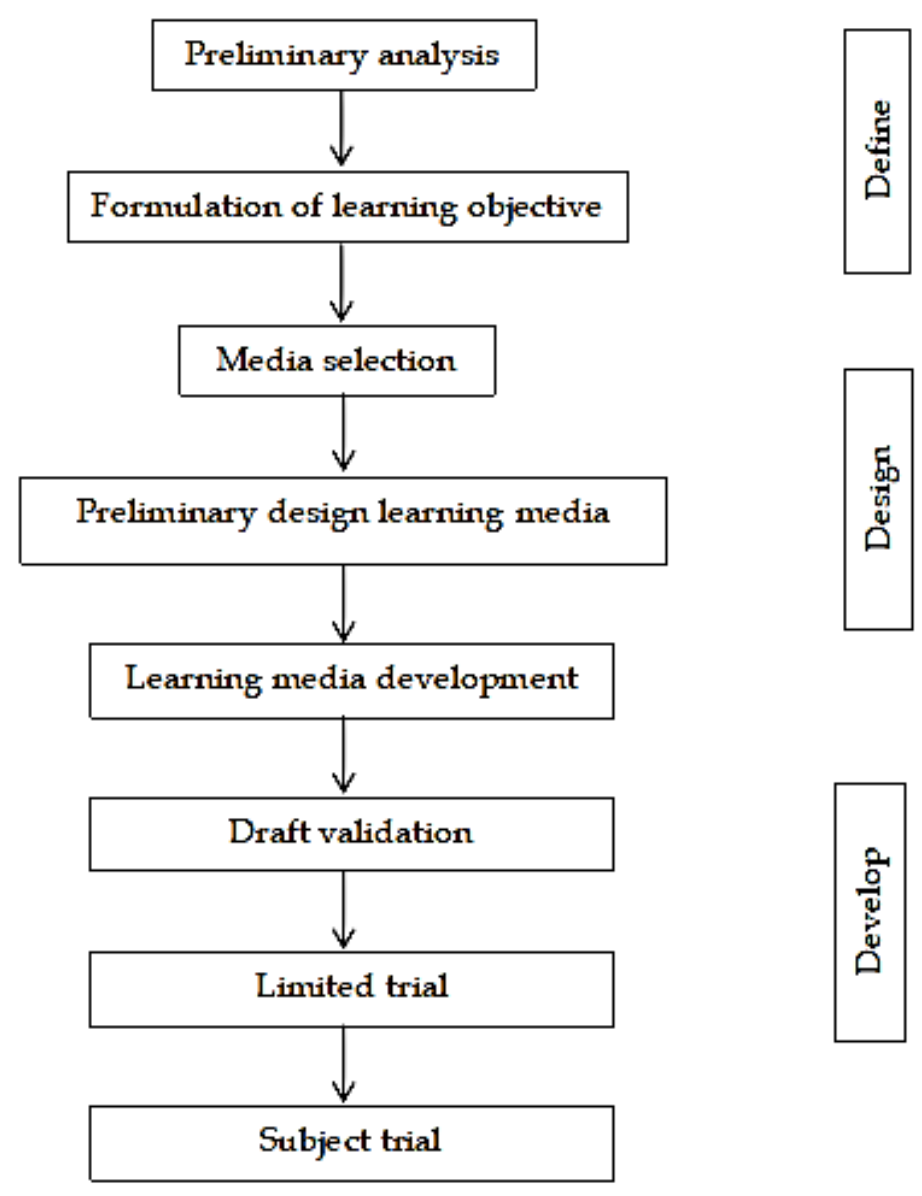

Figure 1. Flowchart of the research procedure. 
The subject of this research is the learning media that consists of syllabus, lesson plan, student activity test, student learning materials, creative thinking test. This study uses One Group Pretest and Post-test. The pretest was given during the initial observation O1 while after the treatment it was called the Post-test O2. The research design is as follows:

$$
\mathrm{O}_{1} \mathrm{XO}_{2}
$$

(Arikunto, 2013)

Describe:

$\begin{array}{ll}\mathrm{O}_{1} & =\text { pretest } \\ \mathrm{O}_{2} & =\text { post-test } \\ \mathrm{X} & =\text { treatment }\end{array}$

The research subjects is a number of fifth grade students at primary school Kejapanan III. In the first stage of the trial, 10 students were taken randomly, then the second stage of the trial used all members of class $\mathrm{V}$ with a total of 30 students in semester 2. This study used the instrument validation sheet for learning tools, learning implementation sheets, creative thinking skills tests and student response questionnaires. The analysis used to obtain the data is as follows 1) Planning, this stage composes the syllabus, lesson plans, teaching materials, student activity sheet, and creative thinking questions which are then validated by experts; 2) Implementation, learning is carried out three times. The pretest was given at the beginning of the treatment and the last was the post-test.

Learning media and instrument desaigned by reacher are given to two expert validator for evaluation. Validator assessed them in validation sheet form value, explanation and suggestion. Result for validation must be categorized valid and feasible. Test score postest increased from pretest after use learning media contextual. The pretest-posttest analysis uses $\mathrm{N}$ gain so that the increase in results after the use of learning tools can be known, as well as what indicators of creative thinking. Then NGain calculation results are then converted with the criteria in Table 1

Table 1. N-Gain Criterion

\begin{tabular}{cc}
\hline N- Gain score & Normalized Gain \\
\hline $0.70<\mathrm{N}$ - Gain & High \\
$0.30 \leq \mathrm{N}-$ Gains $\leq 0.70$ & Moderate \\
$\mathrm{N}-$ Gain $<0.30$ & low \\
\hline
\end{tabular}

Significance of improving Creative Thinking Skills is obtained from hypothesis testing using t-tests with the condition that the analyzed n-gain data should be normally distributed.

\section{RESULTS AND DISCUSSION}

Learning that needs a good preparation, the preparation is applied in to learning tools. Learning tools need some input and suggestions to make them more perfect. In this study, the learning tools used in this study were validated by several experts to produce valid tools. The learning tools are syllabus, lesson plans, student learning material, student activity test, creative thinking test questions. 
Validity learning media

This learning media has been validation by expert in the fields. The results of the validation of learning tools in Table 2.

Table 2. Validation result.

\begin{tabular}{cccc}
\hline Device & Score & Reliability & Category \\
\hline Syllabus & 3,75 & $95,24 \%$ & Valid \& Reliable \\
Lesson plan & 3,56 & $93,16 \%$ & Valid \& Reliable \\
Student learning material & 3,36 & $83,00 \%$ & Valid \& Reliable \\
Student activity sheet & 3,57 & $94,00 \%$ & Valid \& Reliable \\
Creative thinking test & 3,34 & $94,00 \%$ & Valid \& Reliable \\
\hline
\end{tabular}

Based on the results of the validation of the learning tools, it shows valid results and the values between validators show similarities so that they are included in the reliable category. Thus, the syllabus learning tools, lesson plans, teaching materials, student activity sheet and creative thinking test questions can be used in the advanced trial stage (Nieveen, 2013).

\section{Practicaly of Learning}

The practically of learning media is esay or not to implemented or applied by teacher for classroom learning. Learning media that are categorized practical are a) Practicaly lesson plan minimum great category. Lesson plan has practically if easy to use in learning. Thera is an assessment category that is minimum great in percent $\leq 74 \%$. This score from observation during learning; b) Activity student great category. Student activity is the frequency of participant activity learn during the learning takes place. Student activities categorized as good if the average percentage obtained is above $80 \%$

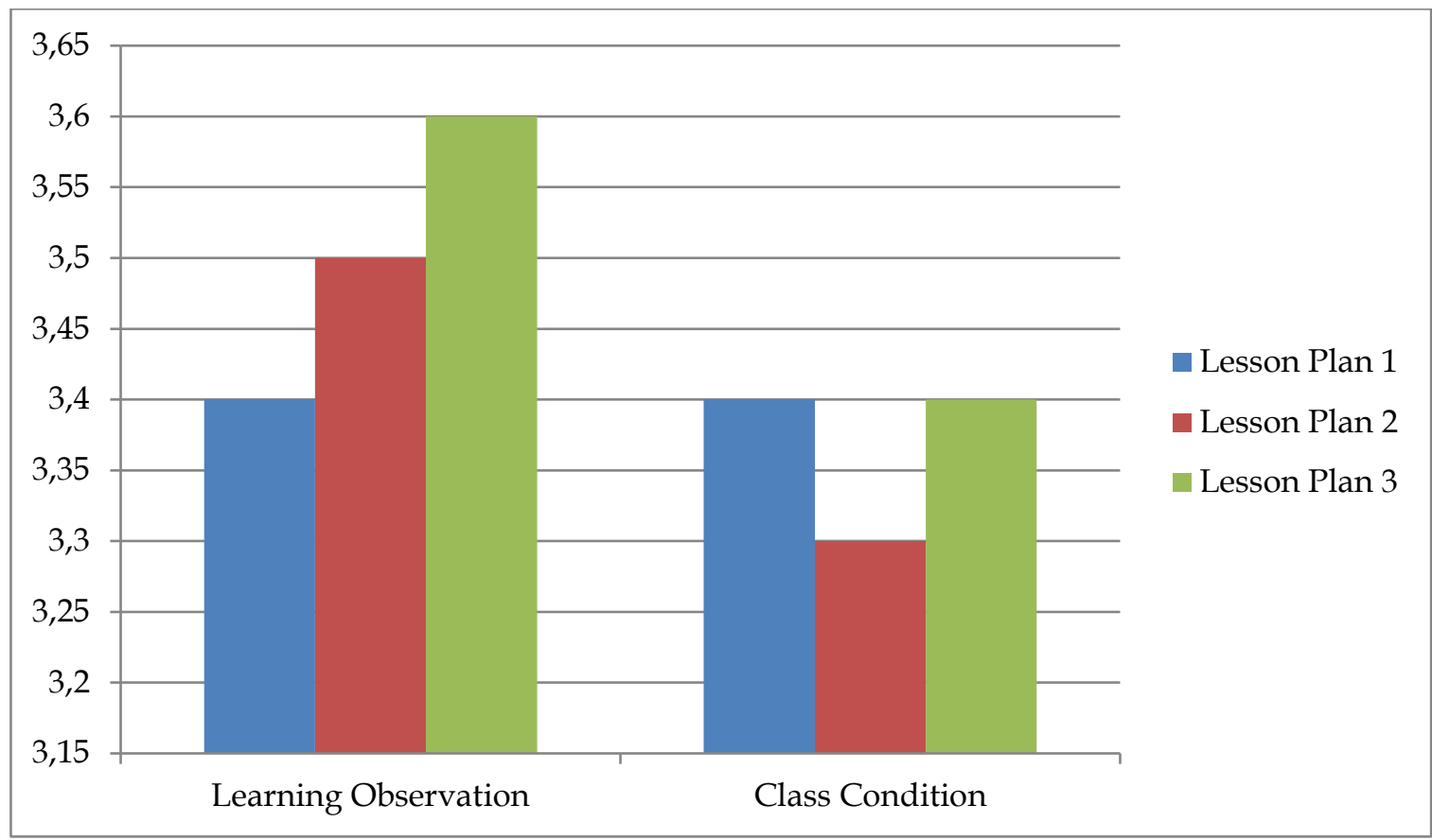

Figure 2. Practical learning. 
Learning is opened with greetings and attendance, then enter the core of learning is that students observe the profile of the warurejo hamlet to knowing the activities carried out in the village, observing activities implemented well and the majority of students were interested. Next activity namely collected information obtained from observations and motivate students to ask questions. In addition to asked students are motivated to try to practice the activities in the student activity sheet (Hendratmoko, 2016). In the second meeting, students were getting used to learning to observe, try and make products. students have adjusted the way of observed, collected information and trying to identify objects that are conductors of heat and isolator heat energy (Arends, 2012). At the third met of the students seemed to enjoy and already know the learning activities to be performed. So that it is more focused on conducting observations, data collection and experiments in contextual learning (Aprizani, 2016). From the results of observations of the practicaly of learning, the percentage of implementation is $77,7 \%$ with high catergory.

\section{Effectiveness learning media}

The effectiveness of learning media can be It is known from the results of the creative thinking skills test and respon student. The results of the pretest and posttest of students' creative thinking test questions after being analyzed using normalized gain (N-Gain) the assessment of creative thinking skills has four indicators that are outlined into seven descriptive items, namely two questions measuring fluency, one question measuring flexibility, two questions measuring authenticity and two questions measuring detail. Learning media are arranged according to the context around students, namely the manufacture of pia cakes, thus helping students relate the material in class to everyday life (Armadi, 2015). In the implementation of the first learning, students still do not know what to do because the learning model is new. Students identify the process of cooking green beans by utilizing complex heat transfer events (Gumrowi, 2015).

Starting from the use of conductors and insulators as the basic ingredients for making pia cakes, the conduction process occurs when heat from the stove as a heat source moves to the pan where the dough is stirred. The convection process and occurs when the heat from the stove moves to the water in the steaming place, the water does not touch the green beans but there is a distance but the green beans can change shape this is a convection event. The learning of the two students seemed to be enjoying the learning model that was applied even though there were some who were not focused and were noisy, but this could be handled well. In the third learning, students were able to work according to orders and could carry out activities properly and correctly, although there were some students who still made noise but had no effect on other friends.

The results of the N-Gain show an increase in students' creative thinking skills after using contextual-based learning tools. A total of 25 students in the medium category, 5 students in the high category. The N-Gain value shows that the contextual-based learning of cakes around students can help train students' creative thinking so as to improve their creative thinking skills. The following are the results of calculating students' creative thinking abilities based on indicators of creative thinking abilities in Table 3. 
Table 3. Creative thinking assessment indicator.

\begin{tabular}{llcccc}
\hline & \multicolumn{1}{c}{ Indicator } & Pretest & Post-test & N - Gain & Category \\
\hline 1 & Fluency & 54 & 91 & 0.75 & High \\
2 & Flexibility & 48 & 96 & 0.98 & High \\
3 & Originality & 63 & 87 & 0.49 & Moderate \\
4 & elaboration & 55 & 79 & 0.49 & Moderate \\
\hline
\end{tabular}

Table 3 shows the increase in students' creative thinking skills. Student responses showed a high percentage of $100 \%$ stating that they were happy because contextualbased learning was new for students (Daryanto, 2014). This has an impact on students, namely enthusiasm in learning and lack of enthusiasm in participating in learning (Alamsyah, 2016). Students feel enthusiastic because they can explore their abilities and can do new things by observing, experimenting and discussing. Meanwhile, students who feel unable to follow will disturb their friends and make noise in the classroom. These events were seen during the first lesson, in the second learning some noise could be minimized because the students who caused the noise could be overcome. The third meeting showed less noise, but still within reasonable limits. The results of the implementation of learning show relatively good results. This is supported by implementation data obtained from practical results assessed by observers when learning using tools developed by researchers (Baron, 2016). The results of practicality show that teachers are able to guide students when learning using tools that have been developed. The first meeting showed that students were still not used to learning according to the developed device, the second meeting the students could adjust their learning using the developed device (Flower et al., 2016). Student activities based on observations made by observers showed students showed observation and experiment activities and even made a product. This shows that students can work on creative thinking test questions if they are trained continuously and show that the device is categorized as valid to use (Wahyuningtiyas, 2018).

The results of increasing creative thinking skills indicators of fluency, flexibility, originality and elaboration in accordance with the N-Gain value show the value in the medium category so that it has increased because the teacher trains the developed learning tools to make the student learning environment in accordance with the 2013 curriculum student-cantered. Based on the effectiveness data, it shows that the learning tools developed from the validation results are proven to be practical in accordance with the results of the implementation of learning and are effective according to the results of the creative thinking skills test. Creative thinking skill needed in $21^{\text {st }}$ century for live (Auliyah, 2021)

Table 4. Paired T-test result.

\begin{tabular}{|c|c|c|c|c|c|c|c|c|c|}
\hline \multicolumn{10}{|c|}{ Paired Samples Test } \\
\hline & & \multicolumn{5}{|c|}{ Paired Differences } & \multirow[t]{3}{*}{$\mathrm{t}$} & \multirow[t]{3}{*}{$\mathrm{df}$} & \multirow{3}{*}{$\begin{array}{l}\text { Sig. } \\
(2- \\
\text { tailed })\end{array}$} \\
\hline & & \multirow[t]{2}{*}{$\begin{array}{c}\text { Mea } \\
\mathrm{n}\end{array}$} & \multirow[t]{2}{*}{$\begin{array}{c}\text { Std. } \\
\text { Deviat } \\
\text { ion }\end{array}$} & \multirow[t]{2}{*}{$\begin{array}{c}\text { Std. } \\
\text { Error } \\
\text { Mean }\end{array}$} & \multicolumn{2}{|c|}{$\begin{array}{l}\text { 95\% Confidence } \\
\text { Interval of the } \\
\text { Difference }\end{array}$} & & & \\
\hline & & & & & Lower & Upper & & & \\
\hline $\begin{array}{c}\text { Pair } \\
1\end{array}$ & $\begin{array}{l}\text { Pretest - } \\
\text { Postest }\end{array}$ & $\begin{array}{c}- \\
35,1 \\
66\end{array}$ & 6,898 & 1,259 & $-37,742$ & $-32,590$ & $\begin{array}{l}- \\
27, \\
92\end{array}$ & 29 & ,000 \\
\hline
\end{tabular}


Table 4 shown result paired $t$ test $p<0.05$ it means difference signification among pretest and posttest value, with $t$ test negative indicate posttest value better pretest. From these results it can be concluded there is a significant increase creative thinking after students train creative thinking contextual-based learning media. This finding line research La Moma (2017) which learning use contextual can increases creative thinking skill. Research creativity skill do Kawuryan et al (2018) with 30 sampe normality tes mogorv smirnov is $0.200>0.05$ it mean data is normal, furthermore result $t$ test is $t$ count $0.04<\mathrm{t}$ Table 0.005 then posttest have difference significant from exsperiment group. Research creativity Widiana, et al (2016) The creative thinking skill increased from Cycle I to cycle II by $16.56 \%$. The multiple intelligence teaching approach aided by mind mapping could increase science learning achievement of the fifth grade students of Primary school 8 Tianyar Barat, Kubu, Karangasem. The science learning achievement increased from Cycle I to Cycle II by $11.46 \%$. Pangemanan (2020) resercr contextual teaching learning for resorveld issue with $t$ test result $t$ count $=4,38>t$ Table $=2,01$. It means contextual teaching learning approach will train an increase lerarning. Toheri, et al (2020) learning with approach contextual learning can increase creativity thinking skill with result difference significant Anova ability of creative thinking sig $0.000<0.005$ it mean contextual learning increases creativity thinking. Lyn Newton (2016) . $21^{\text {st }}$ century need a job that can solve problems and entrepreneur for train student must use the appropriate learning model, contextual learning effective to train it (Lutuling et al., 2018).

\section{CONCLUSIONS}

Based on the discussion result and a study of the research, the learning tools developed were categorized as valid, practical and effective. Based on this research, it produces learning tools in the form of lesson plans, teaching materials, Student activity sheet and creative thinking test questions. Some suggestions based on research are; students' thinking skills can be developed using contextual-based learning media that provide positive results to be applied and developed in other science materials; the application of contextual-based science teaching materials to improve students' thinking skills, teachers must deepen knowledge about the context around students to help link contextual surroundings with science materials; Learning that is related to improving students' thinking skills is very important to be applied to attract student activity and interest. The learning tools used are specifically related to the context of making pia cakes, while the content is heat transfer material and applications carried out in daily life. Students' creative thinking skills can be developed using contextual-based learning tools which provide positive results for learning, so they need to be developed in other science materials. The application of contextual-based science teaching materials to improve students' creative thinking skills, teachers deepen knowledge about the context around students to help students relate contextual surroundings to the existing science material in them. Learning that is related to improving students' thinking skills is very important to be applied to attract students' interest and effectiveness. The development of contextual-based learning tools can be used as a reference in the implementation of the 2013 curriculum. Application of contextual-based science teaching materials to improve creative thinking skills of students, teachers must deepen their knowledge of the context around students to help students associate contextual surroundings with science material contained. This reaserch only in primary school in Kejapanan Village, it 
can develop in either region have peculiarity. The implication of this research development of contextual-based learning media can used as a reference in the implementation of the 2013 curriculum.

\section{REFERENCES}

Alamsyah, N. (2016). Penerapan pendekatan saintifik untuk meningkatkan kreativitas dan hasil belajar siswa dalam mata pelajaran IPA. Jurnal Pendidikan, 1(1), 82-88. doi.org/10.26740/jp.v1n1.p82-96

Amunutu, S., Rede, A., \& Pasaribu, M. (2016). Meningkatkan motivasi dan hasil belajar siswa melalui contextual teaching and learning pada tema lingkungan di kelas II SDN 2 talise. Mitra Sains, 4(3), 28-34.

Aprizani, Y. (2016). Improving reading comprehension using contextual teaching and learning (CTL). Studies in English Language and Education, 3(2), 170-187 doi.org/10.24815/ siele.v3i2.4964

Arends, R. (2012). Learning to teach ninth edition. New York: McGraw-Hill.

Arikunto, S. (2013). Prosedur penelitian suatu pendekatan praktik. Jakarta: Rineke Cipta Dahar

Armadi, A. (2015). Pengembangan perangkat pembelajaran terpadu tipe "connected" Berbasis budaya lokal pada subtem keunikan daerah tempat tinggalku siswa kelas IV sekolah dasar. Tesis. Surabaya: Program Pascasarjana Unesa.

Auliyah, N., Sudibyo, E., \& Munasir. (2021). Analysis of junior high school students creative thinking skills in distance learning. IJORER: International Journal of Recent Educational Research, 2(3), 316-328. doi.org/10.46245/ijorer.v2i3.111

Baron, P. (2016) A cybernetic approach to contextual teaching and learning. Constructivist Foundations, 12(1), 91-100.

Daryanto. (2014). Pendekatan pembelajaran saintifik kurikulum 2013. Yogyakarta: Gava Media.

Diani, R. (2016). Pengaruh pendekatan saintifik berbantuan lks terhadap hasil belajar fisika peserta didik kelas XI SMA Perintis 1 Bandar Lampung. Jurnal Ilmiah Pendidikan Fisika Al- BiRuNi, 5(1), 108-123. doi.org/10.24042/jpifalbiruni.v5i1.108

Eragamreddy, N. (2013). Teaching creative thinking skill. International Journal of English Language \& Translation Studies, 1(2), 124-145.

Flowers, N., Begum, S., Carpenter, D. M. H., \& Mulhall, P. F. (2017). Turnaround success: An exploratory study of three middle grades schools that achieved positive contextual and achievement outcomes using the schools to watch i3 project. RMLE: Research in Middle Level Education, 40(8), 1-14. doi.org/10.1080/19404476.2017.1361295

Gumrowi, A. (2016). Strategi Pembelajaran Melalui Pendekatan Kontekstual dengan Cooperative Learning untuk Meningkatkan Hasil Belajar Gelombang Siswa Kelas XII MAN 1 Bandar Lampung. Jurnal Ilmiah Pendidikan Fisika Al- BiRuNi, 5(2), 108-123. doi.org/10.24042/jpifalbiruni.v5i2.118

Hake, R. R. (1999). Design-based research in physics education: A review. Routledge.

Hendratmoko. (2016). Pengembangan perangkat pembelajaran fisika model inkuiri terbimbing terintregasi,laboraturium virtual untuk melatihkan kemampuan argumentasi ilmiah siswa. Tesis. Universitas Negeri Surabaya. 
Herianto, I. Z., \& Indana, S. (2020). Validitas dan keefektifan lembar kegiatan siswa (LKS) berbasis contextual teaching and learning (CTL) pada materi psikotropika untuk melatihkan kemampuan literasi sains siswa sma. Berkala Ilmiah Pendidikan Biologi (BioEdu), 9(1), 26-32.

Hwang, G. J., Chiu, Li-Yu., Chen, Ching-Hung. ( 2015 ). A Contextual game based learning approach to improving student inquiry based learning performance. Social studies courses, Computer $\mathcal{E}$ Education, 81(1), 113-120. doi.org/10.1016/j.compedu.2014.09.006.

Inayah, N. (2016). Pengembangan perangkat pembelajaran berorientasi pendekatan saintifik pada pokok bahasan pewarisan sifat untuk melatihkan kreativitas ilmiah siswa SMA. Skripsi. Surabaya: Program Pascasarjana Unesa.

Kawuryan, S. P., Hastuti, W.S., \& Supartinah. (2018). Pengaruh model pembelajaran tematik berbasis permainan tradisional dan scientific approach terhadap kemampuan berpikir kreatif. Cakrawala Pendidikan, 37(1),71-84.

Kemendikbud. (2016). Dinamika perkembangan kurikulum 2013 jenjang pendidikan dasar dan menengah. Jakarta: Kemendikbud.

Lotuling, C. F., Ibrahim, N., \& Tumurung, H. (2018). Effectiveness of learning method contextual teaching learning (CTL) for increasing learning outcomes of entrepreneurship education. TOJET: The Turkish Online Journal of Educational Technology, 17(3), 37-46.

Moma, L. (2017). Pengembangan kemampuan berpikir kreatif dan pemecahan masalah matematis mahasiswa melalui metode diskusi. Cakrawala Pendidikan, 36(1), 130-139. doi.org/10.21831/cp.v36i1.10402

Muhlisin. (2012). Pengembangan perangkat pembelajaran ipa terpadu berbasis contextual teaching and learning (CTL) dengan model pembelajaran kooperatif tipe student teams achievement. Journal of Research and Educational Research, 1(2),

Neka, I. K., Marhaeni, A. A. I. N,. \& Suastra, W. (2015). Pengaruh model pembelajaran inkuiri terbimbing berbasis lingkungan terhadap keterampilan berpikir kreatif dan penguasaan konsep ipa kelas V SD gugus VIII kecamatan abang. Jurnal Pendidikan Dasar Ganesha, 5(1), 1-11.

Nieveen, N., \& Folmer, E. (2013). Formative evaluation in educational design research. Educational Design Research, 153(1), 152-169.

Pangemanan, A. (2020). Application of contextual teaching and learning approach on statistics material against student results. International Education Studies, 13(4), 239 252. doi.org/10.5539/ies.v13n4p1

Purwanti, A. D. (2012). Penerapan pendekatan kontekstual untuk meningkatkan minat belajar siswa pada pembelajaran ipa di sekolah dasar. Jurnal Ilmiah Guru: Caraka Olah Pikir Edukatif, 2(1), 1-6.

Rohmawati, E., Widodo, W., \& Agustini, R. (2018). Membangun kemampuan literasi sains siswa melalui pembelajaran berkonteks socio-scientific issues berbantuan media weblog. JPPIPA: Jurnal Penelitian Pendidikan IPA, 3(1), 8-14. doi.org/10.26740/jppipa.v3n1.p8-14

Rusman. (2011). Model-model pembelajaran mengembangkan profesionalisme guru. Jakarta: PT. Raja Grafindo Persada.

Safaruddin, Juhaeni, R Nurhayati, \& Aulia, N. T. (2020). Konsep Dasar Media

Pembelajaran. IEES : Journal of Islamic Education at Elementary School, 1(1). 
Sugiyono. (2013). Metode penelitian pendidikan. Bandung: Alfabeta.

Sugiyono. (2013). Statistika untuk penelitian. Bandung: Alfabeta.

Susanto, A. (2016). Teori belajar dan pembelajaran. Jakarta: Prenada Media Grup

Suwandari, S., Ibrahim, M., \& Widodo, W. (2019). Application of discovery learning to train the creative thinking skills of elementary school student. International Journal of Innovative Science and Research Technology, 4(12), 410-417

Thiagarajan, S., Semmel, D. S., Semmel, M. I. (1974). Instructional development for training teacher of exceptional. Minnesota: Indiana University.

Toheri, Winarso, W., \& Haqq, A. A. (2020). Where exactly for enhance critical and creative thinking: The use of problem posing or contextual learning. European Journal of Educational Research, 9(2), 877-887. doi.org/10.12973/eu-jer.9.2.877

Wahyuningtyas, R. S., \& Wuryadi. (2018). The influence of contextual teaching and learning (CTL) towards chritical thinking and problem solving ability on skeletal system materials. 5th ICRIEMS Proceedings, 5(1), 117-123.

Widiana, I. N., \& Jampel, I. N. (2016). Improving students' creative thinking and achievement through the implementation of multiple intelligence approach with mind mapping. International Journal of Evaluation and Research in Education, 5(3), 246-254.

Widiawati, M. (2019). Penerapan model pembelajaran creative problem solving untuk meningkatkan keterampilan pemecahan masalah pada soal cerita bangun ruang peserta didik kelas v sekolah dasar. Didaktika Dwija Indria, 7(1), 1-10. doi.org/10.20961/ddi.v7i1.29704

Winarti. (2015). Contextual teaching and learning (CTL) untuk meningkatkan kemampuan berpikir kreatif siswa. JPFL: Jurnal Pendidikan Fisika dan Keilmuan, 1(1), 1-8. doi.org/10.25273/jpfk.v1i1.4

\footnotetext{
*Zaky Adhitya Ginanjar Sasmita

Primary Education Study Program, Post Graduate

State University of Surabaya, Indonesia

J1. Rektorat Unesa, Lidah Wetan, Kec. Lakarsantri, Surabaya 60213, Indonesia

Email: zaky.17070855086@mhs.unesa.ac.id
}

Dr. Wahono Widodo

Departement Science Education Program, Post Graduate

State University of Surabaya, Indonesia

Jl. Ketintang, Surabaya 60231, Indonesica

Email: wahonowidodo@unesa.ac.id

\section{Dr. Sifak Indana}

Biology Education Departement, Faculty of Mathematic and Natural Science, Surabaya 60213,

State University of Surabaya, Indonesia

Jl. Ketintang, Surabaya 60231, Indonesica

Email: sifakindana@unesa.ac.id 